\title{
Comparison of Word Reading between Cognitively Normal Elderly and Elderly with Mild Cognitive Impairment according to Word Condition
}

\author{
Soo Jung Lee ${ }^{1}$, Eun Ju Yeon², Ji Hye Yoon ${ }^{3}$ \\ 'Department of Speech-Language Pathology and Audiology, Tongmyong University, Busan, Korea \\ ${ }^{2}$ Gangwon Speech Therapy and Counseling Center, Hongcheon, Korea \\ ${ }^{3}$ Division of Speech Pathology and Audiology, Research Institute of Audiology and Speech Pathology, Hallym University, Chuncheon, Korea
}

Received: January 14, 2021

Revised: February 1, 2021

Accepted: February 1, 2021

Correspondence:

Ji Hye Yoon, PhD

Division of Speech Pathology and

Audiology, Hallym University,

1 Hallimdaehak-gil,

Chuncheon 24252, Korea

Tel: +82-33-248-2224

Fax: +82-33-256-3420

E-mail: j.yoon@hallym.ac.kr

\begin{abstract}
Purpose: The purpose of this study was to compare word reading performance according to word condition between cognitively normal elderly and elderly with mild cognitive impairment. Methods: We studied 21 patients with mild cognitive impairment (MCl) and 21 age-, sex-, and educationmatched cognitively normal older adults. Participants were asked to administer a reading aloud task under four different word conditions (regular words, regular nonwords, irregular words, irregular nonwords). Results: First, the $\mathrm{MCl}$ group scored significantly lower compared to the normal elderly group in irregular both words and nonwords. Although there were no significant group differences in regular words and regular nonwords, both groups showed poor performance in the order of irregular nonwords, irregular words, regular nonwords, and regular words. Second, from the error analyses, the $\mathrm{MCl}$ group made more 'regularization' errors than the normal elderly group in both irregular words and irregular nonwords. Also, in regular nonwords, the $\mathrm{MCl}$ group made more 'phonological errors' than the elderly group. Conclusion: Our findings suggest that $\mathrm{MCl}$ adversely affects lexical routes for reading irregular words. Also, decreased performance in irregular nonwords requiring both reading routes represents the the lexical route is impaired and the phonologicl route is not fully preserved in $\mathrm{MCl}$.
\end{abstract}

Key Words: Aging, Lexical route, Mild cognitive impairment, Phonological route, Reading.

\section{INTRODUCTION}

읽기는 쓰기와 더불어 문자 언어를 사용하는 언어적 활동으 로서, 제시된 시각적 정보를 해독(decoding)하는 과정과 그 정보 를 언어학적으로 이해하는 과정으로 이루어진다(Byrne, 2005). 읽기 처리가 일어나는 과정을 구체적으로 살펴보면, 가장 먼저 시각적 분석이 이루어지는데, 이 단계에서는 시각적으로 제시 된 글자나 단어의 외형적 특성을 관찰하고 통합적으로 분석하 게 된다. 시각적 분석이 끝난 후에는 단어의 친숙함 여부에 따 라 서로 다른 두 가지 읽기 경로, 즉, '어휘통로(lexical route)'와 '음운통로(phonological route)'가 활성화되는데(Ellis \& Young, 2013), '이중경로모델(dual-route model)' (Coltheart, 2005)에서 는 음운통로를 비어휘통로(nonlexical route)로 명명하기도 하

(cc) This is an Open Access article distributed under the terms of the Creative Commons Attribution Non-Commercial License (https://creativecommons.org/licenses/by-nc/4.0) which permits unrestricted non-commercial use, distribution, and reproduction in any medium, provided the original work is properly cited.
나 두 가지 읽기 통로에 대한 기본적인 개념은 동일하다. 시각 적으로 제시된 단어가 이미 머릿속의 어휘사전 내에 저장되어 있는 친숙한 자극일 경우에는 어휘통로가 활성화되며, 심성어 휘집(mental lexicon)에 등록되어 어휘성(lexicality)을 지닌 친 숙한 단어이기만 하면 철자(자소, grapheme)와 소리(음소, phoneme)가 서로 일치되는지 여부와 관계없이 읽기가 가능하게 된 다. 즉, 철자와 소리가 일치하는 규칙 단어(regular word)(예: 가 방)뿐만 아니라 서로 일치하지 않는 불규칙 단어(irregular word) 혹은 자소-음소 불일치 단어(grapheme-phoneme noncorrespondent word)(예: 같이) 역시 어휘통로를 통해 어려움 없이 읽을 수 있게 되는 것이다. 반면, 제시된 단어가 많이 접해보지 않은 생소한 단어이거나 혹은 뜻이 없는 비단어(nonword)(예: 망미)인 경우에는 어휘통로를 통해 읽는 것이 불가능한데, 이 경우에는 음운통로를 활성화시켜 철자에 대응하는 소리로 전 환해서 읽는 절차(grapheme-to-phoneme conversion)를 거쳐 야만 한다. 즉, 철자와 소리의 대응이 일대일로 규칙적인 경우 
에만 음운통로를 통한 읽기가 가능하다.

이렇듯 읽기의 두 가지 처리 경로를 살펴볼 때, 규칙 단어(예: 가방) 및 불규칙 단어(예: 같이)는 이미 어휘집에 등록되어 있 는 단어들이므로 어휘경로를 통해 읽기가 이루어지며, 규칙 비 단어(예: 망미)는 비단어이면서 철자와 소리가 일대일로 대응하 는 자극이므로 음운경로를 통해 읽기가 이루어짐을 알 수 있 다. 한편, 불규칙 비단어(irregular nonword), 즉, 어휘집에 등 록되어 있지 않은 동시에 철자와 소리가 서로 일치하지 않는 자 극의 경우에는 어휘통로와 음운통로가 동시적으로 활성화된다 (Coltheart, 2005). 예컨대, '딥합이라는 불규칙 비단어를 소리 내어 읽는다고 생각해보자. 일단 시각적으로 단어를 재인하는 단계(visual word recognition)에서 어휘성이 없는 비단어라고 판단되면 음운통로가 먼저 활성화되지만, 철자와 소리가 일치 하지 않는 불규칙 단어이기 때문에 음운통로만으로는 읽기가 불가능하다. 이때, 어휘통로를 통해 '딥합'과 외형적인 모양이 비슷한, 즉, 음운조건이 유사한 이미 알고 있는 단어들, 예컨대, '집합(/지팝/)', '힙합(/히팝/)' 등의 단어들을 심성어휘집으로부 터 활성화시켜 공통된 음운변동 규칙을 찾아내야 한다. 최종적 으로는 찾아낸 음운변동 규칙을 목표 불규칙 비단어인 '딥합' 에 올바르게 적용시킬 수 있어야만 /디팝/으로 읽는 것이 가능 해진다. 이와 같은 과정을 살펴볼 때, 불규칙 비단어의 경우, 읽 기 처리 과정에서 음운통로와 어휘통로를 유연하게 오가며 이 들 두 통로들을 필요에 따라 적절히 '활성화' 시키거나 '억제'할 수 있어야만 정확한 읽기가 가능하다(Coltheart, 2005; Yeon et al., 2017).

정상적인 읽기 발달 과정을 거쳐 읽기 기술이 안정된 단계에 이른 성인을 대상으로 한 선행연구를 살펴보면, 청년층, 중년층, 노년층의 세 집단 모두 규칙 단어, 규칙 비단어, 불규칙 단어, 불규칙 비단어 순의 읽기 수행력을 보였으며, 특히 불규칙 비 단어에서의 읽기 수행력이 확연히 낮은 양상을 보였다. 노년층 의 경우, 규칙 단어를 제외한 나머지 세 가지 단어 조건에서 모 두 청년층보다 유의하게 낮은 수행력을 보임으로써 정상 노화 로 인한 읽기 수행력의 감퇴를 보였으며, 특히 철자와 소리가 대응되지 않는 불규칙 단어 혹은 불규칙 비단어 수행력의 저 하를 통해 어휘통로가 노화에 더 취약함을 확인하였다(Yeon et al., 2017). 선행연구를 통해 정상 노화로 인한 읽기 수행의 감퇴 및 읽기 처리 과정에서의 취약점이 확인되었으나, 정상 노 화에서 병리학적 노화로 진행되는 과정에서의 읽기 특성을 파 악하여 이를 임상적인 지표로 활용하기 위해서는 전임상단계 (pre-clinical stage)의 경도인지장애(mild cognitive impairment) 노년층을 대상으로 한 읽기 연구를 살펴볼 필요가 있다. 경도인지장애는 치매의 전단계로서 기억력, 집행기능, 주의집중 력과 같은 인지기능의 저하와 더불어 읽기나 쓰기와 같은 문해
능력에도 부정적 영향을 미치는 것으로 알려져 있으나(Lee et al., 2020; Taler et al., 2009; Weinborn et al., 2018), 안타깝게 도 경도인지장애 노년층을 대상으로 단어 조건에 따른 읽기 수 행력을 측정하고 이를 통해 읽기 처리 과정을 확인한 국내 연구 는 전무하다. 영어권 국가들에서 진행된 일부 선행연구들을 통 해 경도인지장애 노인이 정상 노인에 비해 불규칙 단어 읽기 능 력이 저하된다는 점은 밝혀진 바 있으나(Weinborn et al., 2018), 단어 조건별 읽기 수행력을 비교하지 않아 읽기 처리 과정의 특 성을 확인하기에는 어려움이 있다. 또한, 문자의 고유한 특성은 수행력에 영향을 줄 수 있으므로 한글 수행에서도 타 문자권 사용자들이 보이는 것과 동일한 양상이 관찰되는지 확인할 필 요가 있다. 한글과 영어는 모두 표음문자에 속하나 한글의 경우 각각의 철자가 대체로 일관적으로 대응되는 소리를 가짐으로써 철자-소리 간의 대응이 규칙적인 데 비해 영어는 한글만큼 철 자와 소리 간의 대응이 규칙적이지 않다(Kim \& Cho, 2001). 즉, 한글에서는 발음의 용이성을 충족하기 위하여, 철자와 소리가 일치하지 않는 단어의 조건들이 모두 각 음운들이 결합될 때 음운의 위치와 환경에 수반되어 일어나는 음운변동(phonological rule)(예: 해돋이, 미닫이에서 'ㄷ + l'가 결합될 때의 구 개음화 '-지')에 해당하므로 특정한 규정없이 철자와 소리가 매 우 다채롭게 불일치하는 영어권의 불규칙단어(예: yacht, school, chocolate)와는 구별되는 특성을 가진다. 따라서 이러 한 한글의 특수성 등을 고려하면 결과의 임상적 적용을 위하 여 한글을 모국어로 사용하는 대상자들에 대한 국내 연구가 더욱 필요하다고 하겠다.

이에, 본 연구에서는 경도인지장애 노인과 정상 노인 간 단어 조건(규칙 단어, 규칙 비단어, 불규칙 단어, 불규칙 비단어)에 따른 읽기 수행 양상을 비교하고, 읽기 시 나타난 오류 유형을 비교분석하고자 하였다. 본 연구를 통해 정상 노화 및 경도인 지장애로 인한 읽기 처리 과정의 특성을 확인한다면, 이는 문 어 능력 측면에서 정상 노화와 병리학적 질환을 감별할 수 있 는 임상 지표 중 하나로서 활용될 수 있을 것이다.

\section{MATERIALS AND METHODS}

\section{연구 대상}

본 연구는 연령이 만 60 세 이상인 경도인지장애 노인 21명(건 망성 경도인지장애 13 명, 비건망성 경도인지장애 8 명)과 정상 인지기능을 나타내는 노인 21명 등 총 42명을 대상으로 실시하 였다. 실험군인 경도인지장애 노인은 동아대학교병원 인지장 애-치매 센터를 내원한 환자로, 1) Petersen et al.(2001)의 진단 기준을 적용하여 신경과 전문의로부터 치매 전단계인 경도인지 장애로 진단받고, 2) 치매임상평가척도(clinical dementia rat- 
ing) 0.5 에 해당하며, 3) 뇌졸중, 파킨슨병, 두부 손상 등의 병력 이 없는 환자를 대상으로 하였다. 대조군인 정상 노인의 선정기 준은, 1) 인지 기능에 영향을 미치는 신경학적, 정신과적 질환 의 병력이 없는 자로, 2) 한국판 간이정신상태검사(Korean Mini-Mental State Examination, K-MMSE) (Kang, 2006)의 점수가 연령 및 학력에 따른 규준 비교 시에 정상 범주에 포함 되며, 3) 단축형 노인우울척도(Short form Geriatric Depression Scale, SGDS) (Kee, 1996)에서 8점 이하로 우울감이 없다 고 판단된 노인을 대상으로 하였다. 실험군과 대조군 모두 학력 이 언어 능력에 미치는 영향을 최소화하기 위하여 교육연수를 최소 6년 이상인 자로 제한하였다.

각 집단 별 인구통계학적 특성과 K-MMSE 및 SGDS 점수 는 Table 1에 제시하였다. 두 집단 간 연령, 성별, 교육연수 및 $\mathrm{K}-\mathrm{MMSE}$ 점수에는 통계학적으로 유의한 차이가 없었으나, $\mathrm{SGDS}$ 점수에는 두 집단 간 유의한 차이가 나타났다 $(t=7.199$, $p<0.001)$. 노인에서의 우울 증상은 인지기능 저하를 유발하 는 주요 인자 중 하나로 밝혀져 있으며(Dotson et al, 2010), 치 매나 경도인지장애를 겪는 노인의 경우 정상 노인에 비해 더 많 은 우울감을 보고하는 것으로 알려져 있다(Ismail et al., 2017). 본 연구에 포함된 경도인지장애 노인 역시 정상 노인에 비해 더 많은 우울감을 보이는 것으로 나타났으며, 이에 따라 통계 분 석 시에 SGDS 점수를 공변량으로 설정하여 우울 증상이 단어 읽기 과제 수행에 미칠 수 있는 영향을 통제하였다.

\section{연구 도구}

한국어 읽기검사(Korean Language-based Reading Assessment, KOLRA) (Pae et al., 2015) 중 소리 내어 읽기 과제 를 적용하여 두 집단의 한글 단어 읽기 능력을 평가하였다. 소 리 내어 읽기 과제는 총 4 개의 하위범주(규칙 단어, 불규칙 단 어, 규칙 비단어, 불규칙 비단어)로 나뉘어져 있으며, 각각의 범 주는 2 음절로 이루어진 20 개의 단어로 구성되어 있다. 각각의 단어는 $20 \times 15 \mathrm{~cm}$ 사이즈의 흰색 바탕 종이에 글자크기 170 의 나눔고딕체로 인쇄하였으며(Yeon et al., 2017), 두 집단 모두

Table 1. Demographic information of participants

\begin{tabular}{lccc}
\hline \multicolumn{1}{c}{ Characteristic } & MCI $(\mathrm{n}=21)$ & $\mathrm{CNE}(\mathrm{n}=21)$ & $p$-value \\
\hline Age $(\mathrm{yr})$ & $71.8 \pm 5.5$ & $72.2 \pm 7.2$ & 0.848 \\
Sex $(\mathrm{M}: \mathrm{F})$ & $6: 15$ & $6: 15$ & - \\
Education level $(\mathrm{yr})$ & $9.9 \pm 3.6$ & $9.0 \pm 3.0$ & 0.409 \\
K-MMSE & $26.9 \pm 2.4$ & $26.9 \pm 1.7$ & $>0.999$ \\
SGDS & $7.2 \pm 3.6$ & $1.1 \pm 1.5$ & $<0.001^{* * *}$ \\
\hline
\end{tabular}

Data are presented as mean \pm standard deviation unless otherwise specified. ${ }^{* * *} p<0.001$. MCI: mild cognitive impairment, CNE: cognitively normal elderly, K-MMSE: Korean Mini-Mental State Examination, SGDS: Short form Geriatric Depression Scale
동일한 조건 하에서 단어 읽기 과제를 시행하였다.

\section{연구 절차 및 분석 방법}

연구 대상자에게 연구 목적 및 절차를 충분히 설명하였으며, 연구참여 동의서를 작성 받은 후에 검사를 시행하였다. 일차적 으로 대상자가 선정기준에 부합하는지 선별하기 위하여 기초 건강선별설문지를 시행하였고, 연령 및 성별, 교육연수, 손잡이 등의 기본정보를 수집하기 위한 면담이 이루어졌으며, 이어서 선별검사 및 본검사를 실시하였다. 모든 검사는 독립된 조용한 공간에서 검사자와 대상자 간 1:1 방식으로 진행되었다.

본 검사인 단어 읽기 검사 절차는 다음과 같았다(Yeon et al., 2017). 검사자는 대상자에게 '제가 지금부터 글자가 적힌 단어 카드를 한 장씩 보여드리겠습니다. 단어를 읽으실 때는 중간에 심을 주면서 끊어 읽지 마시고 연결하면서 천천히 읽어주세요' 라고 지시한 후에 단어 카드를 하나씩 제시하였다. 규칙 단어, 불규칙 단어, 규칙 비단어, 불규칙 비단어 순서로 시행하였으 며, 대상자가 검사 도중 피로를 호소하면 1 2분간의 휴식 시간 을 제공한 후 검사를 다시 진행하였다. 검사자는 대상자의 읽 기 수행을 실시간으로 전사하는 동시에 보이스 레코더를 이용 하여 녹음하였다. 본 연구는 동아대학교병원(No. 19-239) 및 한림대학교(No. 2017-04-03)의 승인을 받았다.

단어 읽기 수행을 측정하기 위하여 정오반응 분석과 오류 유 형 분석을 시행하였다. 정오반응 분석의 경우, 목표 정반응은 1 점, 오반응은 0 점으로 채점하였으며, 읽기 시 대상자가 자가수 정을 보인 경우에는 마지막 반응을 최종 반응으로 간주하여 채 점하였다. 오류 유형 분석의 경우, Yeon et al.(2017)의 오류 유 형 분석 방법을 따랐으며, 오류 유형 및 오류 예시는 Appendix에 제시하였다.

\section{신뢰도 검증}

언어병리학 전공 박사 1 명에게 채점 방법 및 오류 유형 분류 기준에 대한 지침을 제공한 후 전체 표집된 자료의 약 $20 \%(8$ 명) 를 임의 선정하여 평가자 간 신뢰도를 구하였다. 읽기 정반응 점 수에 대해서는 평가자 간 일치율 $100 \%$ 를 보였고, 읽기 오류 유 형은 약 $91.7 \%$ 의 일치율을 나타내었다.

\section{통계 분석}

자료의 통계처리는 SPSS 25.0 version (IBM Corp., Armonk, $\mathrm{NY}, \mathrm{USA}$ )을 사용하였다. 첫째, 집단 간 인구통계학적 특성의 차이를 알아보기 위하여 독립표본 $t$-검정을 실시하였다. 둘째, 단어 조건(규칙 단어, 불규칙 단어, 규칙 비단어, 불규칙 비단 어)에 따른 집단 간 읽기 점수를 비교하기 위하여 SGDS 점수를 공변량으로 한 반복측정 공분산분석(repeated measure AN- 
COVA, RM-ANCOVA)을 실시하였다. 셋째, 두 집단 간 단어 읽기 오류 유형을 비교하기 위하여 SGDS 점수를 공변량으로 한 대응별 비교 분석(pairwise comparison)을 시행하였으며, 이때 본페로니 검정(Bonferroni correction)을 적용하여 다중 비교 시의 오류를 수정하였다.

\section{RESULTS}

\section{단어 조건에 따른 집단 간 단어 읽기 정반응 점수 비교}

경도인지장애 노인 집단과 정상 노인 집단 간 단어 읽기 정반 응 점수를 비교하기 위하여 SGDS 점수를 공변량으로 설정하 여 반복측정 공분산분석을 실시하였다. 그 결과, 집단(2요인: 경도인지장애 노인, 정상 노인) $\times$ 단어 조건(4요인: 규칙 단어, 불규칙 단어, 규칙 비단어, 불규칙 비단어)의 상호작용 효과가 유의하지 않았으며 $(\mathrm{F}=1.637, p=0.198)$, 집단에 대한 주효과 $(\mathrm{F}=4.992, p<0.05)$ 와 단어 조건에 대한 주효과 $(\mathrm{F}=47.946$, $p<0.001)$ 는 각각 유의한 것으로 나타났다. 단어 조건에 따른 두 집단 간 수행력을 비교하기 위하여 대응별 비교분석을 실시 한 결과, 불규칙 단어 및 불규칙 비단어 읽기에서 경도인지장 애 노인 집단의 정반응 점수가 정상 노인 집단에 비해 유의하 게 낮았다 $(p=0.038 ; p=0.035)$. 반면, 규칙 단어 및 규칙 비단 어 읽기에서는 두 집단 간 통계적으로 유의한 차이가 나타나지

Table 2. Covariate-adjusted correct responses according to word type for each group

\begin{tabular}{lrrl}
\hline & MCI $(\mathrm{n}=21)$ & $\mathrm{CNE}(\mathrm{n}=21)$ & $p$-value \\
\hline Regular words & $19.658 \pm 0.168$ & $19.961 \pm 0.168$ & 0.287 \\
Irregular words & $14.939 \pm 0.724$ & $17.538 \pm 0.724$ & $0.038^{*}$ \\
Regular nonwords & $15.760 \pm 0.875$ & $17.764 \pm 0.875$ & 0.178 \\
Irregular nonwords & $8.483 \pm 0.873$ & $11.660 \pm 0.873$ & $0.035^{*}$ \\
\hline
\end{tabular}

${ }^{*} p<0.05$. MCI: mild cognitive impairment, CNE: cognitively normal elderly

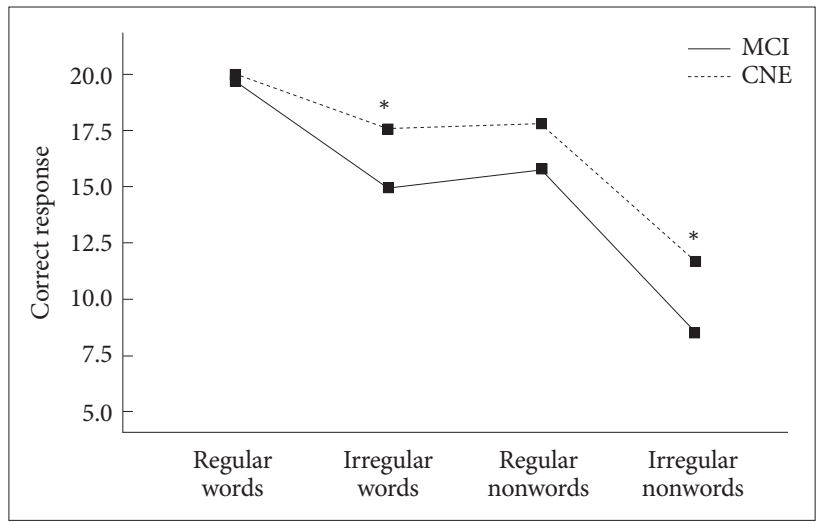

Figure 1. Word reading performance according to word type for each group. ${ }^{*} p<0.05$. MCl: mild cognitive impairment, CNE: cognitively normal elderly.
않았다 $(p=0.287 ; p=0.178)$. 단어 조건에 따른 집단 간 단어 읽기 정반응 점수 비교는 Table 2와 Figure 1에 제시하였다.

\section{단어 조건에 따른 집단 간 읽기 오류 유형 비교}

경도인지장애 노인 집단과 정상 노인 집단 간 단어 읽기 오류 유형별 출현 빈도를 비교하기 위하여 SGDS 점수를 공변량으 로 하여 본페로니 검정을 적용한 대응별 비교분석을 실시한 결 과, 첫째, 규칙 단어의 경우, 오류 유형 네 가지, 즉, 의미적 오류 (semantic error), 타단어화 음운적 오류(formal phonological error), 음운적 오류(phonological error), 분류불가(nonclassifiable) 모두에서 두 집단 간 유의한 차이가 나타나지 않았다. 둘째, 불규칙 단어의 경우, 오류 유형 네 가지 중 규칙화(regularization) 오류에서 경도인지장애 노인이 정상 노인에 비해 오 류 빈도가 높게 나타났으며 $(p=0.021)$, 나머지 오용(misuse), 오용 및 시각적 오류(misuse \& visual error), 분류불가에서는 두 집단 간 유의한 차이가 없었다. 셋째, 규칙 비단어의 경우, 오류 유형 세 가지 중 음운적 오류에서 경도인지장애 노인이 정상 노인에 비해 오류 빈도가 높게 나타났으며 $(p=0.028)$, 나 머지 어휘화(lexicalization) 및 분류불가에서는 두 집단 간 유 의한 차이가 나타나지 않았다. 넷째, 불규칙 비단어의 경우, 오 류 유형 다섯 가지 중 규칙화 오류에서 경도인지장애 노인이 정 상 노인에 비해 오류 빈도가 높게 나타났으며 $(p=0.041)$, 나머

Table 3. Covariate-adjusted number of errors according to word type for each group

\begin{tabular}{lcccc}
\hline & $\mathrm{MCI}(\mathrm{n}=21)$ & $\mathrm{CNE}(\mathrm{n}=21)$ & $p$-value \\
\hline Regular words & & & \\
$\quad$ Semantic error & $0.000 \pm 0.000$ & $0.000 \pm 0.000$ & - \\
Formal phonological error & $0.350 \pm 0.144$ & $-0.064 \pm 0.144$ & 0.094 \\
Phonological error & $0.011 \pm 0.044$ & $0.037 \pm 0.044$ & 0.729 \\
$\quad$ Nonclassifiable & $-0.019 \pm 0.043$ & $0.067 \pm 0.043$ & 0.242 \\
Irregular words & & & \\
$\quad$ Regularization & $1.841 \pm 0.287$ & $0.683 \pm 0.287$ & $0.021^{*}$ \\
Misuse & $1.093 \pm 0.306$ & $0.812 \pm 0.306$ & 0.585 \\
Misuse \& visual error & $1.875 \pm 0.380$ & $0.839 \pm 0.380$ & 0.111 \\
Nonclassifiable & $0.253 \pm 0.130$ & $0.128 \pm 0.130$ & 0.569 \\
Regular nonwords & & & \\
Phonological error & $3.851 \pm 0.672$ & $1.292 \pm 0.672$ & $0.028^{*}$ \\
Lexicalization & $0.460 \pm 0.196$ & $0.254 \pm 0.196$ & 0.533 \\
Nonclassifiable & $0.122 \pm 0.096$ & $0.021 \pm 0.096$ & 0.529 \\
Irregular nonwords & & & \\
Regularization & $4.677 \pm 0.628$ & $2.466 \pm 0.628$ & $0.041^{*}$ \\
Misuse & $1.758 \pm 0.353$ & $2.099 \pm 0.353$ & 0.567 \\
Misuse \& visual error & $2.716 \pm 0.493$ & $1.760 \pm 0.493$ & 0.253 \\
Lexicalization & $1.763 \pm 0.456$ & $1.523 \pm 0.456$ & 0.754 \\
Nonclassifiable & $0.603 \pm 0.282$ & $0.492 \pm 0.282$ & 0.815 \\
\hline
\end{tabular}

${ }^{*} p<0.05$. MCI: mild cognitive impairment, CNE: cognitively normal elderly 
지 오용, 오용 및 시각적 오류, 어휘화, 분류불가에서는 두 집단 간 유의한 차이가 나타나지 않았다. 집단 간 단어 읽기 오류 유 형별 출현 빈도 비교는 Table 3에 제시하였다.

\section{DISCUSSIONS}

본 연구에서는 경도인지장애 노인군과 정상 노인군 간 단어 조건별 단어 읽기 수행 양상을 비교해보고자 하였으며, 그 결 과 두 집단 모두 규칙 단어-규칙 비단어-불규칙 단어-불규칙 비단어' 순으로 수행력이 저하되어 동일한 양상을 보였다. 이러 한 결과는 정상 노년층의 단어 조건에 따른 읽기 능력을 확인 한 선행연구(Yeon et al., 2017)와도 동일한 결과이다. '읽기'와 '쓰기'는 최종적으로 산출되는 운동의 형태가 읽기는 조음기관 의 운동, 쓰기는 손의 운동으로 각기 다르지만, 문어처리과정 내의 어휘통로와 음운통로를 공유한다는 공통점을 지니고 있 다. 이러한 맥락에서 정상 노년층 50대, 60대, 70대의 쓰기 능력 을 비교한 연구(Yoon \& Lee, 2014) 결과를 살펴보면, 연령이 증가함에 따라 규칙 단어나 규칙 비단어에 비하여 불규칙 단 어 쓰기의 수행력이 더 저하됨이 보고되었다. 이러한 불규칙 단 어 쓰기의 수행력 저하는 정상 노화 과정에서 어휘통로의 정보 처리 능력 감소가 반영되었을 가능성을 시사한다. 읽기와 쓰기 는 문자 체계의 처리 과정을 공유한다는 점에서, 선행연구 결 과를 본 연구결과에 투영해 볼 때 불규칙 단어의 읽기 수행력 저하 역시 어휘통로의 기능 저하가 반영된 결과로 해석할 수 있 다. 그러나 본 연구결과에서는 규칙 단어 및 규칙 비단어에 비 해 불규칙 단어 및 불규칙 비단어의 수행력이 낮게 나타나 읽 기 수행 시 어휘성보다는 규칙성이 더 영향을 주는 것으로 나 타났다. 이는 선행연구(Cho \& Pyun, 2015; Kim, 2017)와는 대 조되는 결과인데, 선행연구에서는 규칙 단어 및 불규칙 단어에 비해 규칙 비단어 및 불규칙 비단어의 수행력이 낮게 나타나 어휘성이 읽기 수행에 영향을 주는 것으로 확인된 바 있다. 이 러한 결과의 차이는 연구대상자의 연령이나 학력 차에서 기인 하였을 가능성이 있다. 선행연구에는 20 30대의 학력이 높은 정상 성인이 포함되었으나 본 연구에서는 정상군 및 환자군 모 두 초졸 이상의 60 세 이상 노년층으로 연구대상을 제한하였으 므로 노화로 인한 어휘통로의 능력 감퇴가 직접적으로 투영되 어 단어 조건의 어휘성보다는 규칙성에 더 영향을 받은 것으로 해석해 볼 수 있다.

본 연구에서 나타난 보다 흥미로운 결과는 경도인지장애 노 인이 정상 노인에 비해 '불규칙 단어' 및 '불규칙 비단어'에서의 읽기 수행력이 유의하게 저하되는 양상을 보인 것이다. 이러한 결과는 영어권 국가에서 진행된 노년층 대상의 읽기 연구에서 도 나타난 바 있다. Weinborn et al.(2018)의 연구에 따르면, 경
도인지장애 노인은 정상 노인에 비해 불규칙 단어 읽기 과제에 서 약 3.01점 낮은 점수를 획득하여 두 집단 간 유의한 차이가 나타났다. 이러한 결과는 경도인지장애와 같은 병리적 양상이 읽기 통로에 어떠한 영향을 미치는지를 보여준다. 자소와 음소 가 불일치하는 단어를 읽기 위해서는 어휘통로를 통해서 읽어 야만 하는데, 병리적 양상에 의해 어휘통로가 취약해지면 상대 적으로 양호한 음운통로에 의존하여 읽게 되면서 글자와 소리 가 불일치하는 불규칙 단어 및 불규칙 비단어 읽기 수행력이 더욱 저하되는 것이다. 선행연구들을 통해 읽기나 쓰기 처리과 정의 어휘통로는 주로 좌반구의 두정측두엽(temporoparietal lobe)이나 후하측두엽(posterior inferior temporal cortex) 등 의 영역과 관련이 있는 것으로 보고되어 왔다(Rapcsak \& Beeson, 2004). 경도인지장애를 대상으로 한 뇌영상 연구들을 살펴보면 좌반구의 두정측두엽에서 대사저하(hypometabolism)가 두드러졌으며(Arnáiz et al., 2001), 하측두엽(inferior temporal lobe) 및 두정측두엽 영역에서의 뇌 위축(atrophy) 양 상이 나타나므로(Whitwell et al., 2008), 읽기나 쓰기에서의 어 휘통로 기능 저하를 예측해 볼 수 있다. 또한 경도인지장애는 치매의 전단계로 간주되므로 초기 알츠하이머 치매 환자들의 병리적 소견을 통하여 경도인지장애에서 관찰될 수 있는 뇌의 변화나 기능저하 양상을 유추해볼 수 있다. 초기 알츠하이머 치매 환자들의 뇌 영상 분석에서 두정측두엽 및 하측두엽 등 의 병변이 관찰되며(Whitwell et al., 2011), 이들 뇌 영역이 어 휘철자집에 접근하여 글자를 처리하는 어휘통로와 관련이 있 기 때문에 알츠하이머병의 초기 단계부터 규칙 단어 및 규칙 비단어에 비하여 불규칙 단어의 읽기나 쓰기 수행력 저하가 관 찰된다는 점은 꾸준히 보고되어 왔다(Hwang et al., 2017; McKay et al., 2007; Patterson \& Hodges, 1992; Patterson et al., 1994). 이러한 측면에서 볼 때, 본 연구는 치매의 전단계인 경도인지장애 단계에서부터 정상 노화와는 구별되는 어휘통로 의 처리능력 저하가 시작되어 음운변동이 적용되어야 하는 불 규칙 요소가 포함된 단어들의 읽기 수행력이 뚜렷하게 감퇴함 을 확인하였다.

특히, 불규칙 비단어 읽기의 경우, 어휘통로만을 사용하여 읽 어낼 수 있는 불규칙 단어와 다르게 어휘통로와 음운통로를 유 연하게 오가며 읽기를 수행해야 하는 과제에 해당된다. 비단어 를 읽기 위해서는 기본적으로 음운통로를 통해 읽기가 수행되 지만, 불규칙 비단어의 경우, 동일한 음운변동 규칙을 따르는 기존 어휘들을 활성화시킨 다음 이러한 음운변동 규칙만을 추 출하여 음운통로를 통한 비단어 읽기에 투사 및 적용할 수 있 어야만 올바른 읽기가 가능하다. 예컨대, “낟이”라는 불규칙 비 단어를 읽을 때, 대상자는 먼저 음운통로를 활용하여 목표 단 어에 포함된 음운정보를 분석하게 된다. 동시에 어휘통로를 활 
성화시켜 심성어휘집 안의 음운조건이 유사한 불규칙 단어(예: 맏이, 굳이 등)들을 최대한 활용하여 '구개음화라는 음운변동 을 찾아낸 목표 단어에 적용가능한 음운변동이라 판단되면 이 를 적용하여 “낟이”를 /나지/로 읽어야 한다. 이때, 음운변동 규 칙을 활용하기 위하여 어휘집에 저장된 기존 어휘들을 활성화 시키는 단계에서 기존 어휘로 대체하여 잘못 읽지 않고 음운변 동만을 선택적으로 활용하기 위해서는 언어능력 이외에도 선 택적 주의나 억제, 작업기억과 같은 전두엽 집행기능이 요구된 다. 또한, 두 가지 읽기 통로를 유연하게 오가며 필요한 정보들 을 서로 통합시키는 처리과정은 상당히 복잡하고 세밀한 조율 이 필요한 고차원적 인지활동에 해당하므로, 하나의 통로만을 활용해서 읽기를 수행하는 단어 조건(예: 규칙 단어, 규칙 비단 어, 불규칙 단어)에 비하여 인지적 부담(cognitive load)이 더욱 높아지게 된다. 정상 노화 과정에서도 작업기억 및 집행기능은 감퇴하나(Kirova et al., 2015), 경도인지장애 노년층의 경우에는 이렇듯 두 가지 읽기 통로를 유연하게 오가며 불규칙 비단어를 읽어내기 위해 필요한 인지적 기능들, 즉, 선택적 주의력이나 반 응 억제(response inhibition), 과제 전환능력(task switching), 인 지적 유연성(cognitive flexibility)과 같은 전두엽 집행기능이 정 상 노인에 비해 더욱 뚜렷하게 저하된다는 점이 보고되어 왔다 (Belleville et al., 2007; Traykov et al., 2007; Zheng et al., 2012). 즉, 불규칙 비단어 읽기 과제는 여러 단어 조건들 중 인지적 부 담이 가장 높은 과제이므로, 정상 노인에서도 불규칙 비단어 조건에서의 읽기 수행력이 가장 낮게 나타났으며, 경도인지장 애 노인의 경우에는 정상 노인에 비하여 더욱 유의하게 낮은 수 행력이 관찰된 것으로 간주된다. 결과적으로 이러한 연구 결과 는 인지적 부담이 높은 과제에 대한 경도인지장애 노인의 취약 성을 잘 보여주는 결과이다.

경도인지장애 노인과 정상 노인 집단 간 읽기 오류 유형을 분 석하였을 때, 경도인지장애 노인은 정상 노인에 비해 불규칙 단 어 및 불규칙 비단어 모두에서 글자 그대로 읽는 오류, 즉 '규칙 화' 오류를 거의 두 배 정도로 유의하게 더 많이 보였다(예: 불규 칙 단어: 봄비/봄삐/ $\rightarrow /$ 봄비/, 불규칙 비단어: 딥합/디팝/ $\rightarrow /$ 딥 합/). 불규칙 단어 및 불규칙 비단어는 어휘통로를 통해 음운변 동 규칙을 적용하여 읽어야만 하는 과제들인데, 경도인지장애 노인은 복잡한 인지처리 과정을 통해 음운변동을 적용하지 못 하고 제시된 단어를 글자 그대로 읽은 것으로 해석할 수 있다. 그러나 이러한 결과가 경도인지장애 노인의 음운통로가 정상적 으로 기능한다는 것을 의미하는 것은 아니다. 규칙 비단어 읽 기에서 두 집단 간 오류 유형을 비교했을 때, 경도인지장애 노 인이 정상 노인에 비해 '음운적 오류'(예: 둔촐 $\rightarrow$ 둔출/)를 유의 하게 더 많이 보였는데, 이러한 결과는 음운통로를 통한 읽기 수행 역시 저하되었을 가능성을 시사한다. 즉, 경도인지장애 노
인이 정상 노인에 비해 어휘통로뿐만 아니라 음운통로를 통한 읽기 처리 능력이 모두 저하됨을 보여준다. 그러나 오용이나 시 각적 오류에서 두 집단 간 차이가 없었던 결과는 4,50 대의 중 년층에 비해 60대 이상 노년층의 오용이나 시각적 오류가 유의 하게 많았던 선행연구 결과(Yeon et al., 2017)에 근거하여 볼 때, 비록 정상 노화과정에 해당할지라도 난이도가 높은 불규칙 단어 및 불규칙 비단어 과제에서 음운변동을 잘못 적용할 수 있음을 의미한다.

경도인지장애가 치매의 전단계로 간주되는 맥락에서 추가적 으로 주목할 점은, 본 연구의 경도인지장애 노인은 불규칙 단 어 읽기 시에 규칙화, 시각적 오류, 오용 순으로 오류율이 높아 규칙화 오류를 가장 빈번하게 보인 것에 반해, 우리나라 초기 혹은 중기 알츠하이머 치매 환자를 대상으로 진행된 연구 (Hwang et al., 2017)에서는 시각적 오류, 규칙화, 오용 순으로 시각적 오류의 빈도가 가장 높아 경도인지장애와 치매의 오류 특성 양상이 다를 수 있음을 보여준다. 즉, 알츠하이머 치매 환 자는 목표 단어의 음소를 시각적으로 전혀 다른 음소로 잘못 지각하는 오류(예: 학교 $\rightarrow$ 함교, 굳이 $\rightarrow$ 굼이)를 가장 많이 보였 다. 알츠하이머 치매는 병이 진행될수록 시지각 처리 능력에 결 함을 보인다는 사실에 주목해 볼 때(Mandal et al., 2012), 경도 인지장애에서 치매로 진행될수록 불규칙 단어 읽기 시에 어휘 통로를 활성화하여 음운변동 규칙을 적용하기 전단계인 시지각 분석 및 처리 단계에서부터 오류를 범하게 되는 것으로 해석해 볼 수 있겠다. 알츠하이머 치매에서의 시지각 처리 결함이 단어 읽기 능력 저하와 관련성이 있으며, 이는 알츠하이머병에서 나 타나는 좌측 측두-후두엽(temporo-occipital lobe)의 신경병리 학적 변화와 관련됨이 보고된 바 있다(Glosser et al., 2002). 추 후, 정상 노인, 경도인지장애 노인, 알츠하이머 치매 노인군을 대상으로 동일한 읽기 자극을 사용한 후속 연구가 진행된다면 병의 진행에 따른 단어 읽기 양상을 파악하고 신경병리학적 변 화와의 관련성을 유추해 볼 수 있을 것이다.

결과 해석 시 주의할 점은 두 집단 모두 다른 오류 유형보다 규칙화 오류의 비율이 높았는데, 이는 대상자들이 제시된 불규 칙 비단어를 보고 각각의 음절을 하나씩 분절하여 읽었을 가 능성을 완전히 배제할 수 없음을 시사한다. 즉, 자신의 어휘목 록에 들어있지 않은 비단어를 읽어야 할 때 두 통로 중 음운통로 만을 활성화시켜서 각 음절을 읽는 읽기처리과정에서의 개인적 선호도가 반영되었을 가능성이 있기 때문이다. 이러한 경향은 정 상 청년을 대상으로 한 선행연구(Lee \& Kim, 2003)에서도 관찰 되었는데, 일부 청년 대상자들이 불규칙 단어에서는 모두 정반 응 수행을 보인 반면, 불규칙 비단어에서는 음운변동을 잘 적 용하지 못하는 양상을 보였다. 따라서 추후 연구에서는 불규칙 비단어와 동일한 음운변동을 포함하면서 외형적으로 유사한 
불규칙 단어를 함께 혹은 따로 제시할 때의 수행력 양상을 비 교하여 읽기 통로의 선호도 및 점화(priming)의 영향을 확인하 고, 수행력 저하의 기전을 탐색할 필요가 있겠다.

본 연구는 경도인지장애 노인과 정상 노인 집단 간 단어 읽 기 비교를 통하여 전임상적 단계의 병리적 인지감퇴가 읽기 처 리 과정에서 어휘통로 및 음운통로를 활용하는 데 있어 어떠한 영향을 미치는지 탐구고자 하였다. 그 결과, 경도인지장애 노인 은 어휘통로뿐만 아니라 음운통로를 통한 읽기 처리 능력이 모 두 저하되며, 나아가 이 두 가지 통로를 선택적으로 활용하여 통합하는 능력 역시 저하됨을 확인하였다. 이러한 결과는 문어 능력 측면에서 정상 노화와 병리적 질환을 서로 감별할 수 있 는 기초자료로 활용될 수 있으며, 치매로 진행되기에 앞서 병리 적 변화를 조기에 발견할 수 있는 진단적 근거를 제공하였다는 점에서 의의가 있다.

본 연구의 제한점은 다음과 같다. 교육수준과 연령은 읽기 능력에 영향을 줄 수 있으므로 결과에 영향을 주는 변인을 최 대한 통제하기 위하여 각 집단 별 대상자의 배경정보를 매칭형 식으로 통일하였다. 그러나 42명의 표본을 대상으로 하였으므 로 결과의 일반화에서 주의가 요구된다. 또한 본 연구는 치매의 전임상적 단계에 해당하는 경도인지장애를 대상으로 하였으나, 건망성 경도인지장애와 비건망성 경도인지장애가 모두 포함되 었다는 제한점이 있다. 이에, 추후 연구를 통해 경도인지장애군 의 이질성을 최소화한 단일 집단을 대상으로 한 연구가 시행될 필요가 있을 것이다. 더불어, 후속 연구에서는 인지장애 스펙트 럼의 연속선상에서 치매 집단까지 포함하여 읽기와 함께 쓰기 능력을 확인할 수 있다면 인지수준에 따른 전반적인 문어 능력 감퇴에 대한 임상적 근거를 제시하는 데 도움이 될 것이다. 마 지막으로는 행동수행 자료와 뇌영상 자료의 관련성을 확인하 여 한글 읽기의 뇌신경학적 기제를 탐색할 필요가 있겠다.

중심 단어 : 노화·어휘통로·경도인지장애·음운통로·읽기.

\section{Ethical Statement}

This study was approved by the Institutional Review Board of Dong-A University Medical Center (No. 19-239) and Hallym University (No. 2017-04-03). Written informed consent was obtained from all participants.

\section{Acknowledgments} $\mathrm{N} / \mathrm{A}$

\section{Declaration of Conflicting Interests}

There are no conflict of interests.

\section{Funding}

This research was supported by Hallym University Research Fund in 2020 (No. HRF-202012-013).

\section{Author Contributions}

Conceptualization: Soo Jung Lee, Ji Hye Yoon. Data curation: Soo Jung Lee, Eun Ju Yeon. Formal analysis: Soo Jung Lee, Eun Ju Yeon. Funding acquisition: Ji Hye Yoon. Investigation: Soo Jung Lee, Eun Ju Yeon. Methodology: Soo Jung Lee, Ji Hye Yoon. Supervision: Ji Hye Yoon. Validation: Soo Jung Lee. Visualization: Soo Jung Lee. Writing_original draft: Soo Jung Lee. Writing - review \& editing: Ji Hye Yoon. Approval of final manuscript: all authors.

\section{ORCID iDs}

Soo Jung Lee

Eun Ju Yeon

Ji Hye Yoon

\begin{abstract}
https://orcid.org/0000-0003-0954-5181 https://orcid.org/0000-0002-9347-199X https://orcid.org/0000-0003-1403-2276
\end{abstract}

\section{REFERENCES}

Arnáiz, E., Jelic, V., Almkvist, O., Wahlund, L. O., Winblad, B., Valind, S., et al. (2001). Impaired cerebral glucose metabolism and cognitive functioning predict deterioration in mild cognitive impairment. Neuroreport, 12(4), 851-855.

Belleville, S., Chertkow, H., \& Gauthier, S. (2007). Working memory and control of attention in persons with Alzheimer's disease and mild cognitive impairment. Neuropsychology, 21(4), 458-469.

Byrne, B. (2005). Theories of Learning to Read. The Science of Reading: a Handbook (pp. 104-119). Oxford: Blackwell Publishing.

Cho, H. \& Pyun, S. B. (2015). Characteristics of acquired phonological dyslexia in Korean. Communication Sciences and Disorders, 20(4), 570586.

Coltheart, M. (2005). Modeling reading: The dual-route approach. The Science of Reading: A Handbook (pp. 6-23). Oxford: Blackwell Publishing.

Dotson, V. M., Beydoun, M. A., \& Zonderman, A. B. (2010). Recurrent depressive symptoms and the incidence of dementia and mild cognitive impairment. Neurology, 75(1), 27-34.

Ellis, A. W. \& Young, A. W. (2013). Human Cognitive Neuropsychology: a Textbook with Readings. Psychology Press.

Glosser, G., Baker, K. M., de Vries, J. J., Alavi, A., Grossman, M., \& Clark, C. M. (2002). Disturbed visual processing contributes to impaired reading in Alzheimer's disease. Neuropsychologia, 40(7), 902-909.

Hwang, J. E., Kim, H., Cho, S. R., Yoon, J. H., Hwang, J. E., Kim, H., et al. (2017). Word Lexicality- and regularity-dependent alexia in Alzheimer's Disease. Communication Sciences and Disorders, 22(1), 129-137.

Ismail, Z., Elbayoumi, H., Fischer, C. E., Hogan, D. B., Millikin, C. P., Schweizer, T., et al. (2017). Prevalence of depression in patients with mild cognitive impairment: a systematic review and meta-analysis. JAMA Psychiatry, 74(1), 58-67.

Kang, Y. (2006). A normative study of the Korean Mini-Mental State Examination (K-MMSE) in the elderly. Korean Journal of Psychology, 25, 1-12.

Kee, B. S. (1996). A preliminary study for the standardization of geriatric depression scale short form-Korea version. Journal of Korean Neuropsychiatric Association, 35(2), 298-307.

Kim, H. J. \& Cho, J. R. (2001). Phonological awareness, visual perception, and reading of Hangul in preschool children. Korean Journal of Developmental Psychology, 14, 15-28.

Kim, W. J. (2017). Comparison of reading performance between persons with aphasia and normal adults according to lexicality and regularity (Master's thesis). Seoul: Ewha Womans University.

Kirova, A. M., Bays, R. B., \& Lagalwar, S. (2015). Working memory and executive function decline across normal aging, mild cognitive impairment, and Alzheimer's disease. BioMed Research International, 2015, $1-9$

Lee, H. S., Cho, E. B., Na, D. L., \& Yoon, J. H. (2020). Comparison of Wordwriting performance according to the degree of cognitive decline: fo- 
cused on patients with subjective memory complaint, mild cognitive impairment, and Alzheimer's disease. Audiology and Speech Research, 17(1), 91-102.

Lee, H. S. \& Kim, J. O. (2003). The effects of ease with phonological rules applicability on phonological processing of Korean words and nonwords. Korean Journal of Experimental Psychology, 15(3), 425-454.

Mandal, P. K., Joshi, J., \& Saharan, S. (2012). Visuospatial perception: an emerging biomarker for Alzheimer's disease. Journal of Alzheimer's Disease, 31(s3), S117-S135.

McKay, A., Castles, A., Davis, C., \& Savage, G. (2007). The impact of progressive semantic loss on reading aloud. Cognitive Neuropsychology, 24(2), 162-186.

Pae, S., Kim, M., Yoon, H., \& Jang, S. (2015). Korean language based reading assessment (KOLRA). Seoul: Hakjisa.

Patterson, K. E., Graham, N., \& Hodges, J. R. (1994). Reading in dementia of the Alzheimer type: a preserved ability? Neuropsychology, 8(3), 395407.

Patterson, K. \& Hodges, J. R. (1992). Deterioration of word meaning: implications for reading. Neuropsychologia, 30(12), 1025-1040.

Petersen, R. C., Doody, R., Kurz, A., Mohs, R. C., Morris, J. C., Rabins, P. V., et al. (2001). Current concepts in mild cognitive impairment. Archives of Neurology, 58(12), 1985-1992.

Rapcsak, S. Z. \& Beeson, P. M. (2004). The role of left posterior inferior temporal cortex in spelling. Neurology, 62(12), 2221-2229.

Taler, V., Klepousniotou, E., \& Phillips, N. A. (2009). Comprehension of lexical ambiguity in healthy aging, mild cognitive impairment, and mild Alzheimer's disease. Neuropsychologia, 47(5), 1332-1343.

Traykov, L., Raoux, N., Latour, F., Gallo, L., Hanon, O., Baudic, S., et al. (2007). Executive functions deficit in mild cognitive impairment. Cognitive and Behavioral Neurology, 20(4), 219-224.

Weinborn, M., Bucks, R. S., Sohrabi, H. R., Rainey-Smith, S. R., Brown, B. M., Gardener, S. L., et al. (2018). Trajectories of irregular word reading ability as a proxy for premorbid intelligence in Alzheimer's disease, mild cognitive impairment, and healthy aging: a longitudinal study. Psychological Assessment, 30(10), 1308-1316.

Whitwell, J. L., Jack Jr, C. R., Przybelski, S. A., Parisi, J. E., Senjem, M. L., Boeve, B. F., et al. (2011). Temporoparietal atrophy: a marker of AD pathology independent of clinical diagnosis. Neurobiology of Aging, 32(9), 1531-1541.

Whitwell, J. L., Shiung, M. M., Przybelski, S. A., Weigand, S. D., Knopman, D. S., Boeve, B. F., et al. (2008). MRI patterns of atrophy associated with progression to $\mathrm{AD}$ in amnestic mild cognitive impairment. Neurology, 70(7), 512-520.

Yeon, E. J., Cho, E. B., Lee, S. J., Kim, S. W., Lee, Y., \& Yoon, J. H. (2017). Characteristics of word reading according to word condition in normal adults. Communication Sciences and Disorders, 22(4), 730-744.

Yoon, J. H. \& Lee, E. O. (2014). Characteristics of orthographic retrieval with age in the elderly. Phonetics and Speech Sciences, 6(1), 119-125.

Zheng, D., Dong, X., Sun, H., Xu, Y., Ma, Y., \& Wang, X. (2012). The overall impairment of core executive function components in patients with amnestic mild cognitive impairment: a cross-sectional study. BMC Neurology, 12(1), 138. 
APPENDIX $\square$

\section{읽기 오류 유형의 분류 및 오류 예시}

\begin{tabular}{|c|c|c|c|}
\hline 단어 & 유형 & 정의 & 오류 예시 \\
\hline \multirow[t]{4}{*}{$\begin{array}{l}\text { 규칙 단어 } \\
\text { (Regular words) }\end{array}$} & $\begin{array}{l}\text { 의미적 오류 } \\
\text { (Semantic error) }\end{array}$ & $\begin{array}{l}\text { 제시된 단어를 다른 음소로 대치하여 의미적으로 } \\
\text { 연관된 단어로 읽는 경우 }\end{array}$ & - \\
\hline & $\begin{array}{l}\text { 타단어화 음운적 오류 } \\
\text { (Formal phonological } \\
\text { error) }\end{array}$ & $\begin{array}{l}\text { 제시된 단어를 다른 음소로 대치하여 다른 단어로 } \\
\text { 읽는 경우 }\end{array}$ & 교장 $\rightarrow /$ 고장/ \\
\hline & $\begin{array}{l}\text { 음운적 오류 } \\
\text { (Phonological error) }\end{array}$ & 목표어의 일부 음소를 다른 음소로 대치하는 경우 & 정상 $\rightarrow$ /성상/ \\
\hline & 분류불가(Nonclassifiable) & 기타 분류할 수 없는 경우(신조어 포함) & 콜라 $\rightarrow /$ 골타/ \\
\hline \multirow[t]{4}{*}{$\begin{array}{l}\text { 불규칙 단어 } \\
\text { (Irregular words) }\end{array}$} & 규칙화(Regularization) & $\begin{array}{l}\text { 음운변동을 적용하지 않고 제시된 글자를 그대로 읽는 } \\
\text { 경우 }\end{array}$ & 봄비/봄삐/ $\rightarrow$ 봄비/ \\
\hline & 오용(Misuse) & $\begin{array}{l}\text { 음운변동을 적용하려고 시도는 하였으나, 음운변동을 } \\
\text { 일부 적용하거나 또는 잘못 적용한 경우 }\end{array}$ & 굳이/구지/ $\rightarrow /$ 구치/ \\
\hline & $\begin{array}{l}\text { 오용 및 시각적 오류 } \\
\text { (Misuse \& visual error) }\end{array}$ & $\begin{array}{l}\text { - 제시된 단어의 음소를 다른 음소로 대치 또는 생략 } \\
\text { 하는 시각적 오류를 보여서 음운변동이 적용되지 } \\
\text { 않은 경우 } \\
\text { - 음운변동도 잘못 적용했을뿐 아니라 시각적 오류도 } \\
\text { 함께 보인 경우 }\end{array}$ & $\begin{array}{l}\text { 닫는/단는/ } \rightarrow / \text { 담는/ } \\
\text { 놓다/노타/ } \rightarrow \text { 놉따/ }\end{array}$ \\
\hline & 분류불가(Nonclassifiable) & 기타 분류할 수 없는 경우(신조어 포함) & 빻은/빠은/ $\rightarrow /$ 발근/ \\
\hline \multirow{3}{*}{$\begin{array}{l}\text { 규칙 비단어 } \\
\text { (Regular } \\
\text { nonwords) }\end{array}$} & $\begin{array}{l}\text { 음운적 오류 } \\
\text { (Phonological error) }\end{array}$ & 목표어의 일부 음소를 다른 음소로 대치하는 경우 & 종둗 $\rightarrow /$ 종둔/ \\
\hline & 어휘화(Lexicalization) & 비단어를 단어로 읽은 경우 & 다돈 $\rightarrow /$ 단독/ \\
\hline & 분류불가(Nonclassifiable) & 기타 분류할 수 없는 경우 & 부브 $\rightarrow /$ 부슥/ \\
\hline \multirow{5}{*}{$\begin{array}{l}\text { 불규칙 비단어 } \\
\text { (Irregular } \\
\text { nonwords) }\end{array}$} & 규칙화(Regularization) & $\begin{array}{l}\text { 음운변동을 적용하지 않고 제시된 글자를 그대로 읽는 } \\
\text { 경우 }\end{array}$ & 딥합/디팝/ $\rightarrow$ 딥합/ \\
\hline & 오용(Misuse) & $\begin{array}{l}\text { 음운변동을 적용하려고 시도는 하였으나, 음운변동을 } \\
\text { 일부 적용하거나 또는 잘못 적용한 경우 }\end{array}$ & 떻다/떠타/ $\rightarrow$ 떠따/ \\
\hline & $\begin{array}{l}\text { 오용 및 시각적 오류 } \\
\text { (Misuse \& visual error) }\end{array}$ & $\begin{array}{l}\text { - 제시된 단어의 음소를 다른 음소로 대치 또는 생략 } \\
\text { 하는 시각적 오류를 보여서 음운변동이 적용되지 } \\
\text { 않은 경우 } \\
\text { - 음운변동도 잘못 적용했을뿐 아니라, 시각적 오류도 } \\
\text { 함께 보인 경우 }\end{array}$ & $\begin{array}{l}\text { 솥옷/소돋/ } \rightarrow \text { /손옫/ } \\
\text { 답합/디팝/ } \rightarrow / \text { 팀합/ }\end{array}$ \\
\hline & 어휘화(Lexicalization) & 비단어를 단어로 읽은 경우 & 족말/종말/ $\rightarrow /$ 족빨/ \\
\hline & 분류불가(Nonclassifiable) & 기타 분류할 수 없는 경우 & 덥말/덤말/ $\rightarrow /$ 더빨/ \\
\hline
\end{tabular}

*Yeon et al.(2017)에서 인용, 부분 수정하였음 